\title{
Thoughts on Algae Cultivation toward an Expansion of Aquaculture to the Scale of Agriculture
}

\begin{abstract}
Amir Neori and Lior Guttman
National Center for Mariculture, Eilat, Israel Oceanographic \& Limnological Research, Eilat, Israel

Abstract: Today's fish - dominated seafood consumption pattern cannot be sustained, since supply has shifted from capture to culture (each currently at around 100 million tons/y). Already today, seaweeds (macroalgae) and shellfish dominate mariculture. To prevent crises, wise policies could anticipate this inevitable shift, by promoting seaweed and shellfish production and consumption. The current rate of expansion in mariculture production will inevitably rise in the long run. Eventually, the seafood share in global food supplies, primarily in $3 r d$ world countries, will rise, with the emerging global exhaustion of arable land and freshwater reserves. The sea remains the world's last food frontier - the only environment that is still available for expansion of food production. A sustainable expansion of seafood culture by orders of magnitude necessitates a balance, as in agriculture, between fed aquatic animals (fish, shrimp...) and extractive plants and animals (bivalves, detritivores). Extractive organisms ameliorate the environmental impacts of the fed animals' farming, while bringing more income and jobs. Cultured seaweeds, with their biochemical composition and high protein content, can also replace much of the fishmeal in aquaculture diets and provide humanity with nutritious protein.
\end{abstract}

Keywords: abalone, algae, bivalves, ecosystem services, fish, mariculture, periphyton, plankton, sea-urchins, seaweed, shrimp, sustainability water quality

\section{Introduction}

Growth in population and food consumption per capita encounter an agriculture that is stagnated by diminishing resources of arable land, fertilizers and irrigation water, all worsened by climate change. Mariculture can avoid these limitations, by being located on the ocean and on desert lands, using seawater and nutrients from the sea or from wastewater. Therefore, mariculture remains the ultimate expandable source of food. Since the 1970's aquaculture has been the fastest-growing -food-producing sector, with an average annual growth rate of over six percent. Seaweed cultivation in seawater is an established 30 million tons (fw/y) industry, $3 / 4$ of it for food. Its current growth rate of a doubling/decade will bring the seaweed production to 8 billion ton (!) by 2100 . Increasing the industry's growth to 1.2 doublings/decade will make it match agriculture by 2100 (!).

Closing the food gap with seafood requires raising mariculture - aquaculture in seawater - $(70 \%$ of the world's surface, receiving most of the world's sunshine and containing huge amounts of nutrients, e.g., $10^{11}$ ton phosphorus) and on non-arable lands (deserts cover about a third of the continents). To realize its potential, mariculture should be socially acceptable and environmentally benign, or better - even beneficial to natural ecosystems (i.e., providing ecosystem services). Algae as extractive photo-autotrophs are the prime candidate aquatic crops $[11,18]$. A huge quantity of microalgae, $1 / 4$ billion ton $\mathrm{fw} / \mathrm{y}$, is already in regular production as cheap feed for filter feeders, mainly in SE Asian 'greenwater' polyculture, using farm waste as fertilizer [12]. While many algae can be cultured, the development of engineering concepts for the low-cost production of huge quantities of them in seawater remains a challenge. The engineering challenges are great but surmountable. Our generation's policy-makers, engineers and aquaculturists can help mankind by promoting this mariculture 
industry, to ensure sufficient supply of nutritious food and maintain a habitable global environment for the generations to come.

\section{Large Scale Algal Culture}

Seaweeds can produce cheap nutritious biomass. The economically important seaweed species have been cultured commercially and profitably for decades. Thirty million ton (fw) a year is the latest figure from FAO (Food and Agriculture Organization of The United Nations), at an average market value of \$30-40 / ton fw. Most of this production takes place in coastal ocean water in several SE Asian countries [3]. It makes sense to consider seaweed production on the open sea on a much larger scale. Hundreds million tons fw of microalgae already form the basis of the polyculture of fish industry in SE Asia and additional countries, including Israel. The production of low-cost microalgae populations in greenwater has a great promise, both in water impoundments and in nitrified open water.

\subsection{Large Seaweed Farms Offshore.}

Seaweed have been cultured profitably for decades, mainly in coastal ocean waters in SE Asia [3, 18, 13]. Some algae make excellent food for humans and livestock, and their production in large seaweed farms off-shore can turn vast expanses of sea into eco-friendly cultivated fields, which require minimal structures (using the natural buoyancy of, e.g., Sargassum spp.). Seaweed farming on the High Seas, with deep water pumping as has been proposed in the US OTEC [9] and the Japanese TAKUMI [8], reduces the pressure on near shore ecosystems and agriculture resources. Huge seaweed farms, as the proposed 100- $\mathrm{km}^{2}$ rafts [17], could drift with currents, until harvested, in the Central Gyres - "ocean deserts" of the major oceans, especially the Pacific, with its nutrient - rich deeper water. The aforementioned upwelling pumps [8,9] can draw water with nutrients from their main global store- deeper oceanic waters merely hundreds of meters deep, especially in the Pacific Ocean or near polluted ocean water. One such raft can produce $0.8-2.5 \times 10^{6}$ tons ( $\mathrm{fw}$ ) of seaweed a year. Matching present global agriculture output with seaweed will require thousands such rafts, covering $10^{6} \mathrm{~km}^{2}$ of water, $<1 \%$ of the global ocean area. The massive yield of seaweed biomass will supply - food, feed, bio-fuel and high-value compounds (bio-gels, pigments etc.) [3]. Furthermore, seaweed cultivation provides valuable ecosystem services [18].

\subsection{Seaweed in Integrated Multi-Trophic Aquaculture (IMTA) Farms - Saltwater Aquaponics - Offshore}

The suite of coastal and on-shore integrated sustainable mariculture technologies developed and implemented today can triple farm productivity per ton of used feed and water. The technologies are generic and modular, adaptable for fish and shrimp culture at any level of intensification. Marine fish, shrimp, seaweed, oysters, clams, abalone and sea urchins already grow in demonstration and fully commercial integrated farms. Algal-based integrated mariculture off-shore provides a working approach for the necessary expansion of the industry. The location of huge farms of fed fishcages in open water, surrounded with bivalve units, as was done in Canada [4] and in Sanggou Bay, China [5] can produce large quantities of fish, shellfish and seaweeds. The nutrients-loaded fishcage effluents create nutrient-rich surface plumes, which can imitate an upwelling by nutrifying large areas of the ocean's surface and support seaweed production.

The uniqueness of these approaches is in the merging of commercial monoculture technologies of the specific organisms, some of them heterotrophs and others photoautotrophs. An integrated farm is a simplified version of the natural ecosystem, where sunlight drives the recycling of heterotrophic metabolites and the purifying of water. Sales of seaweeds and shellfish, already the largest global mariculture two sectors, compensate the cost involved with sustainable mariculture. A culture system that diversifies its products by integrating the fed culture of fish/shrimp with an extractive algal culture and with algivores/filter feeders, makes therefore much sense, not only ecologically but also economically. These same benefits characterize the modern offspring of traditional polyculture, i.e., IMTA. In such farms, nutrient release and uptake are balanced. Be it in 
coastal waters or in ponds, effluents from the intensive culture of the fed fish support adjacent intensive cultures of extractive crops - seaweeds, and also (via phytoplankton) - filter feeding shellfish and bottom feeders.

\subsection{IMTA with constructed wetlands}

Wetlands planted with the halophyte Salicornia spp. (glasswort, pickle weed, marsh samphire) have been incorporated into a two-species IMTA [21]. Salicornia is a genus of a valuable fresh vegetable crop that thrives in harsh saline and seawater conditions with yields that can surpass 250 ton fw/ha/y. A fish-wetland IMTA offers the farm the use of a marginal soil or gravel as a substrate instead of ponds. The Salicornia shoots have an established and growing market for the health food, nutraceutical and beauty industries.

\subsection{Periphyton- based Biofilters}

Seaweeds preferentially use ammonia over nitrate-nitrogen. Recent research has indicated that periphyton biofilters might have a more balanced uptake of both $\mathrm{N}$ forms [7]. Periphyton represents a class of photosynthetic-based biofilters capable of removing inorganic nutrients from aquaculture waste with minimal aeration costs. Periphyton is the aquatic biota (bacteria, algae and micro- and small macro-fauna) that develops as a natural film on submerged substrates when nutrients and light are available. Autotrophic and heterotrophic organisms in periphyton are capable of metabolizing organic and inorganic nitrogen forms and phosphorus. Periphyton can also remove toxic hydrogen sulphide via autotrophic nitrate reduction and anoxygenic photosynthesis. Photosynthesis and denitrification are the prime processes that improve water quality by periphyton, by oxygenation, reducing excess carbon dioxide and ammonia, and stabilization the $\mathrm{pH}$ levels in the fish pond. The produced biomass is a nutritious feed for fish and shrimp, reducing by up to 50\% the use of commercial aquafeed for a given production. The capacity of periphyton biomass to take up simultaneously, without an exceptional preference, both ammonia and nitrate has been recently demonstrated. In ammoniadepleted effluents, nitrate uptake rate (probably by denitrification) and efficiency rose about five folds (unpublished). A dual Ulva-periphyton biofilter revealed a synergistic treatment of nutrient-rich mariculture effluents, removing up to $76 \%$ of the total nitrogen, $97 \%$ of the ammonia and of $67 \%$ of the nitrate.

\subsection{Large Scale Algal Culture on Land}

Schemes for very large marine seaweed farms in coastal deserts have been proposed, one of the more ambitious ones is The Green Desert Project (GDP), a concept for re-greening the Sahara, through Integrated Aqua-Agro Biotechology (IAAB) [13]. Most of the technologies needed to form the IAAB are already applied at a commercial scale, but not integrated. The concept fulfils several basic requisites for the successful production of cheap algae in the Saraha and similar deserts [13]. These requisites include very low-cost seawater pumping + fertilizers $(\mathrm{N} \& \mathrm{P})+\mathrm{CO}_{2}$, cheap coastal flatland and in latitudes below $30^{\circ}$. The project proposes to begin with several 2-ha farms on shebkhas (salty low flatlands) below sea level bordering the coasts of Mauritania, Western Sahara, Morocco, Algeria, Tunisia and Libya. Nutrient-rich deep ocean water should gravity-flow in huge quantities into the depression, used by several crops on the slopes and eventually collect and evaporate at the bottom. The concept is based on IMTA with fish, seaweed, shrimp, microalgae, mollusks, cyanobacteria, worms, halophytic land plants and other organisms, depending on market considerations, local species and local conditions in each farm. Beneficial side effects include a reduction in the rise in sea level through the hydration of the desert and reduction in the rise of atmospheric $\mathrm{CO}_{2}$.

\subsection{Microalgae Culture in 'Greenwater' Aquaculture}

Much of global fish culture production takes place in environmentally friendly, extensive, labor-intensive traditional freshwater polyculture farms in SE Asia. In such farms, nutrients recycle via algae between fish of different and complementary trophic feeding habits. In polyculture, the conversion of pollution to more fish brings monetary, social and environmental benefits. A recent estimate of production of 'green water' algae in pond polyculture came up with > 250 million metric tons fw/y of pond-grown 'green water' algae, consumed by 
planktivorous fish and shrimp. A roughly similar quantity is ingested by bivalves in coastal marine farms. The total algal use is several folds larger than total world aquaculture production reported by the FAO.

'Green water' plankton - microalgae, bacteria, fungi, protozoa, small zooplankton etc. - is cultured in manmade water impoundments, fertilized by manure and other village waste, and is supplemented occasionally by aqua-feeds. Mariculture of bivalves depends on 'natural' plankton in coastal water. It is debatable how natural this plankton is, given that water near populated coasts is often enriched by anthropogenic nutrients.

While the traditional polyculture fish farmers sell fish, they raise microalgae in the first place. As the largest sector in aquaculture, 'green water' plankton deserves a much larger R\&D effort than it receives today. Scientific attention and budgets allocated to 'green water' may cost-effectively raise world seafood production. Studies could improve the understanding and control of planktonic food webs, develop polyculture in seawater and domesticate market-attractive marine planktivorous fish.

\subsection{Principles of Algal Biofilter Design and Operation}

Removal of total ammonia is the main role of algae in the integrated mariculture farm [15]. The biofilter's ammonia removal, which correlates with algal yield and its $\mathrm{N}$ content, should, therefore, be matched with ammonia production. Optimal seaweed density should be sufficient to absorb incident light, with the biomass harvested upon doubling. Most seaweed-based integrated systems studied have used the robust, predictable and reliable Ulva spp. and Gracilaria spp. Microalgal-based systems usually depend on the algae that develop naturally, as influenced by water exchange rate, silicate additions, pond depth and other factors. The maximal biofiltration occurs of course in daytime. Land-based culture of seaweed in tanks, ponds and ditches has been developed in most places with the bottom-aerated pond approach developed by the group led by Ryther in the 1970's, as reviewed by [15]. A spray/drip culture of seaweed biofilters has also been studied [10].

\section{Economics}

Expansion of seaweed farming to scales that approach conventional agriculture depends on the demand for seaweeds and their products, development of farming methods that compete in cost and scale, and recognition of the ecological services seaweed farms can provide. Excepting specialty and gourmet products, global demand for seaweeds is closely dependent on whether agriculture will satisfy growing food, feed and biofuel needs [1]. It is argued here, that production of seaweed for food and for fuel may depend on each other. Only the biofuel market is large enough to absorb the uneaten fractions of billion-ton quantities of seaweed biomass, and only the revenues from seaweed protein can make seaweed biofuel economically-competitive with other options. This codependency, however, may shift as farmed-seaweed products gain status as food and for other uses on their own merits [18]. The profitability of 'green water' polyculture is (not exclusively) the result of: (a) the low cost of growing 'green water' plankton, (b) the value of village waste disposal by the polyculture pond, and (c) the sustainability of polyculture. Therefore, its products can be cheap and attractive for large markets.

In the cost sheet of a modern intensive fish culture farm, the cost of fish feed proteins constitutes the largest item. Yet, often $3 / 4$ of the proteins fed to the fish end up as dissolved ammonia. Algae recapture from the water and recycle ammonia, carbon dioxide, orthophosphate and micronutrients back into useful, protein-rich (>35\% in $\mathrm{dw}$ ) biomass. Seaweed farms on land can be profitable. Huguenin and the Ryther group have already predicted it in the 70's [6], and the farm of Acadian Sea plants (http://www.acadianseaplants.com/) in Canada and Seakura (http://www.seakura.net/) in Israel have operated for years. It is logical that synergism can improve the profitability of an integrated farm, composed of two independently profitable farms (e.g., fish and seaweed), particularly once the value of the ecosystem services is rewarded by the authorities and the market.

The followings all need to be considered in the assessment of the economic viability of a seaweed-based integrated mariculture system: cost of land, energy and labour; access to clean seawater, supplies, marketing, shipping and other services; availability of educated and/or technically oriented staff; political, business and financial infrastructures that can support or at least understand a hi-tech agricultural project. It is therefore 
difficult to compare the situation in different countries. Such considerations have been shown to apply to several farms $[16,19,22]$. The by-production of high-quality seaweed in the biofilters calls for the co-culture of marine macroalgivores. The quantitative aspects of the three stage integrated cultivation of fish, seaweed, and abalone were assessed [20]. Data from a commercial pilot study and from the commercial farm conservatively suggest for a 1- ha farm, the annual production of 50 tons seabream, 33 ton abalone and 333 tons seaweed, all of which should be eaten by the abalone. Seaweed sales and savings in waste control are likely to profitably cover the extra cost associated with the seaweed biofilters [2]. Low cost seaweed production promises to have a large market. It has been shown, that the lower the trophic level of an aquacultured species, the lower can be its production cost and the larger can be its market [14].

\section{Acknowledgements}

We acknowledge relevant discussions with H. Cronin, A. Israel, J.L.G. Pinchetti, R. Radulovich, M. Shpigel and N. Tadmor-Shalev. The authors dedicate this publication to the late G. Garcia-Blairsy Reina, who shared with us his ideas.

\section{References}

[1] Baghel, R.S., Trivedi, N., Gupta, V., Neori, A., Reddy, C.R.K., Lali, A. and Jha, B. (2015). Biorefining of marine macroalgal biomass for production of biofuel and commodity chemicals. Green Chem., 17, 2436-2443.

https://doi.org/10.1039/C4GC02532F

[2] Buschmann, A.H., Troell, M., Kautsky, N., Kautsky, L. (1996). Integrated tank cultivation of salmonids and Gracilaria chilensis (Gracilariales, Rhodophyta). Hydrobiologia, 326/327, 75-82.

https://doi.org/10.1007/BF00047789

[3] Buschmann, A.H., Camus, C. et al. (2017). Seaweed production: overview of global state of exploitation, farming and emerging research activity. Eur. J. Phycol. Festschrift 52, 391-406.

https://doi.org/10.1080/09670262.2017.1365175

[4] Chopin, T., Cooper, J.A.J., Reid, G., Cross, S., Moore, C. (2012). Open-water integrated multi-trophic aquaculture: environmental biomitigation and economic diversification of fed aquaculture by extractive aquaculture. Rev. Aquacult., 4, 209-220.

https://doi.org/10.1111/j.1753-5131.2012.01074.x

[5] Fang, J., Zhang, J., Xiao, T., Huang, D., Liu, S. (2016). Integrated multi-trophic aquaculture (IMTA) in Sanggou Bay, China. Aquacult. Env. Interact., 8, 201-205.

https://doi.org/10.3354/aei00179

[6] Huguenin, J.H. (1976). AN examination of problems and potentials for future large-scale intensive seaweed culture systems, Aquaculture 9, 313-342.

https://doi.org/10.1016/0044-8486(76)90074-0

[7] Levy, A., Milstein, A., Neori, A., Harpaz, S., Shpigel, M., Guttman, L. (2017). Marine periphyton biofilters in mariculture effluents: Nutrient uptake and biomass development. Aquaculture, 473, 513-520.

https://doi.org/10.1016/j.aquaculture.2017.03.018

[8] Masuda, T., Furuya, K. et al. (2010). Lagrangian observation of phytoplankton dynamics at an artificially enriched subsurface water in Sagami Bay, Japan. J. Oceanogr., 66, 801-813.

https://doi.org/10.1007/s10872-010-0065-1

[9] Mencher, F. M., Spencer, R. B., Woessner, J. W., Katase, S. J., Barclay, D. K. (1983). Growth of nori (Porphyra tenera) in an experimental OTEC-aquaculture system in Hawaii. J. World Mar. Soc., 14, 456-70.

https://doi.org/10.1111/j.1749-7345.1983.tb00098.x 
[10] Msuya F.E., Neori A. (2010). The performance and chemical composition of spray-irrigated seaweed Ulva lactuca as a crop and as a biofilter of fishpond effluents. J. Phycol., 4, 813-817.

https://doi.org/10.1111/j.1529-8817.2010.00843.x

[11] Neori, A. (2008). Essential role of seaweed cultivation in integrated multi-trophic aquaculture farms for global expansion of mariculture: an analysis. J. Appl. Phycol., 20, 567-570.

https://doi.org/10.1007/s10811-007-9206-3

[12] Neori, A. (2011). 'Green water' microalgae: The leading sector in world aquaculture. J. Appl. Phycol., 23, 143-149. https://doi.org/10.1007/s10811-010-9531-9

[13] Neori, A. (2016). Can sustainable mariculture match agriculture's output? Global Aquaculture Advocate, August 18, 2016, available on-line at: https://www.aquaculturealliance.org/advocate/can-sustainable-mariculture-match-agricultures-output/

[14] Neori, A., Nobre, A. M. (2012). Relationship between trophic level and economics in aquaculture. Aquacul. Econ. \& Manag., 16, 40-67.

https://doi.org/10.1080/13657305.2012.649046

[15] Neori, A., Chopin, T. et al. (2004). Integrated aquaculture: rationale, evolution and state of the art, emphasizing seaweed biofiltration in modern mariculture. Aquaculture, 231, 361-391.

https://doi.org/10.1016/j.aquaculture.2003.11.015

[16] Nobre, A.M., Robertson-Andersson, D., Neori, A., Sankar, K . (2010). Ecological-economic assessment of aquaculture options: comparison between abalone monoculture and integrated multi-trophic aquaculture of abalone and seaweeds. Aquaculture, 306, 116-126.

https://doi.org/10.1016/j.aquaculture.2010.06.002

[17] Notoya, M. (2010). Production of biofuel by macro-alga with preservation of marine resources and environment. In: Role of Seaweeds in Future Globally Changing Environments (Einav, R. and Israel, A., Eds.), in the series: Cellular Origin, Life in Extreme Habitats and Astrobiology (Seckbach, J., Ed.), Springer, Dordrecht, vol 15, part 5, pp. 217-228.

[18] Radulovich R., Neori A. et al. (2015). Farming of seaweeds, in Seaweed sustainability - food and nonfood applications (Tiwari, B. and Troy, D., Eds.), Acad. Press, London, ch. 3, pp. 27-59.

https://doi.org/10.1016/B978-0-12-418697-2.00003-9

[19] Ridler, N., Wowchuk, M., et al (2007). Integrated multi trophic aquaculture (IMTA): A potential strategic choice for farmers. Aquacult. Econ. Manag., 11, 99-110.

https://doi.org/10.1080/13657300701202767

[20] Shpigel, M. and Neori, A. (1996). Abalone and seaweeds intensive cultivation in integrated land-based mariculture system. I. Proposed design and cost analyses. Aquacult. Eng., 15, 313-26.

https://doi.org/10.1016/0144-8609(96)01000-X

[21] Shpigel, M., Ben-Ezra, D., Shauli, L., Sagi, M., Ventura, Y., Samocha, T., \& Lee, J.J. (2013). Constructed wetland with Salicornia as a biofilter for mariculture effluents. Aquaculture, 412-413, 52-63.

https://doi.org/10.1016/j.aquaculture.2013.06.038

[22] Troell, M. (2009). Integrated marine and brackishwater aquaculture in tropical regions: research, implementation and prospects, in: A Global review of Integrated Marine Aquaculture (D. Soto, Ed.). FAO Fisheries and Aquaculture Technical Paper 529, 47-131. 